\title{
SAVIĆ MARKOVIĆ ŠTEDIMLIJA O PODRIJETLU SRPSKOG KOMUNIZMA I PARTIZANSKOG POKRETA
}

Stipe KLJAIĆ

Hrvatski institut za povijest

Zagreb, Hrvatska

\author{
UDK: 94(497.5)“1930-1945“ \\ 929 Štedimlija, Savić Marković \\ DOI: https://dx.doi.org/10.21857/y26kec3lq9 \\ Pregledni rad \\ Prihvaćeno: 2. siječnja 2019.
}

Savić Marković Štedimlija bio je crnogorski publicist, književnik i pisac. Sudjelovao je u hrvatskom javnom životu od tridesetih godina prošlog stoljeća do kraja rata. Dolazak u Zagreb, u kojem je tada bujao hrvatski nacionalni pokret protiv beogradske diktature, jugoslavenskog nacionalizma i komunističke propagande, presudno je utjecalo na smjer kasnijih Štedimlijinih pogleda. U Zagrebu je njegov crnogorski nacionalizam postao razrađeniji i izoštreniji, pišući ondje svoja najznamenitija djela o crnogorskim pitanjima. Istovremeno se odrekao komunističke ljevice. Branio je ratni pokušaj hrvatske i crnogorske samostalnosti i izjašnjavao se kao neprijatelj zajedničke jugoslavenske države. Ulagao je napore u objašnjenje pojave partizanskog i četničkog pokreta u Drugom svjetskom ratu. $S$ obzirom na to da je partizanski pokret prema kraju rata pokazivao daleko veću opasnost za opstanak ratne hrvatske države, razmjerno tomu davao mu je u svojim spisima daleko veći prostor. Nastojao je stoga pojasniti zbog kojih se razloga tako munjevitom brzinom među srpskim narodom počeo širiti partizanski pokret pod odlučujućim vodstvom srpskih i jugoslavenskih komunista.

Ključne riječi: Savić Marković Štedimlija, partizanski pokret, srpski komunizam, Nezavisna Država Hrvatska.

\section{UVOD}

Drugi svjetski rat u Hrvatskoj i jugoistočnoj Europi često se puta doživljavao u skladu s kutom promatranja komunističke ljevice kao globalni ideološki sukob na crti antifašizam - fašizam. Kako su jugoslavenski komunisti djelovali kao produžena ruka moskovske „svjetske revolucije“, otuda njihova naklonost da rat na prostoru Hrvatske i jugoistočne Europe proglase internacionalnim sukobom na spomenutoj crti. Taj je rat na spomenutim područjima u svojoj srži ipak bio najvećim dijelom nastavak političke krize koja je potresala staru Jugoslaviju. Konačno, i sami su jugoslavenski komunisti u ratu, kako bi zadobili podršku, koristili politički diskurs, koji je više prostora poklanjao rješenju nacionalnog pitanja nego revolucionarnoj problematici. Uspostava Nezavisne Države Hrvatske i raspad Kraljevine Jugoslavije u travnju 1941. dodatno su zaoštrili sukob između političkog hrvatstva i jugoslavenstva, čiji su glavni nositelji bile srpske političke 
snage. ${ }^{1} S$ jedne je strane stajao ustaški pokret i Pavelićev režim koji su se borili u okolnostima rata za osiguranje hrvatske državnosti te s druge strane ustanički pokret koji se borio za ponovnu obnovu Jugoslavije i koji se u početku sastojao od četnika i komunista. Jugoslavenski komunisti od ljeta 1941. poslije napada Njemačke na SSSR daju tom sukobu novi ton. U svojoj političkoj propagandi obećavaju "nacionalno i socijalno oslobođenje“, no i dalje ostaju privrženi jugoslavenskom nacionalizmu. Naravno, ovaj se morao mijenjati uslijed propasti Jugoslavije i ratnih okolnosti, tako da se čuvajući jugoslavenski nacionalizam više nije govorilo o jednom jugoslavenskom narodu kao za stare Jugoslavije, već o „narodno-oslobodilačkom“ jugoslavenstvu, koje „nosi slobodu, ravnopravnost i bratstvo svim narodima Jugoslavije“. ${ }^{2}$

Znatne zasluge za intelektualizaciju antipartizanskog diskursa u NDH pripadaju svakako Saviću Markoviću Štedimliji (1906. - 1971.), ${ }^{3}$ čovjeku

1 Ljubo Antić, Hrvatski komunisti i nacionalni identitet, Kolo - ćasopis Matice Hrvatske za književnost, umjetnost i kulturu, sv. 19, br. 1-2, Zagreb 2009., 160. Antić je komentirao da se pojačana nacionalizacija u retorici hrvatskih komunista osjećala u početnim godinama rata jer je „činjenica što su hrvatski Srbi nerazmjerno osobito u početku participirali u partizanskom pokretu, pa se je ovaj mogao narodu predstaviti kao srpska stvar. Distanciranju od jugoslavenstva doprinosila je i činjenica da se drugi, konkurentski četnički pokret koji je u suštini bio velikosrpski, pozivao na jugoslavenstvo.“

2 Josip B. Tiтo, Nacionalno pitanje u Jugoslaviji u svjetlosti narodnooslobodilačke borbe, Proleter, decembar 1942., Govori i članci, sv. 1, Zagreb, 1959., 120.

3 Rodio se u selu Stijena, u blizini Podgorice 1906., kao potomak crnogorskog plemena Pipera. Nadimak Štedimlija dobio je po brdu Štedim iznad rodnog mu sela. Već se zarana uključuje u napeta politička zbivanja u Crnoj Gori kada se kao trinaestogodišnjak uključuje u borbe s crnogorskim komitama na strani jugoslavenskog oružništva 1919. Poslije toga su ga vlasti kao podgoričkog gimnazijalca izbacile iz škole pod optužbom da se dao u komunistički aktivizam. Pod progonima vlasti radi komunizma luta po Srbiji, pa u Leskovcu tek 1930. završava gimnaziju. Za vrijeme diktature kralja Aleksandra preselio se u Zagreb. Tamo osim pohađanja studija prava i filozofije razvija svoj publicistički i novinarski talent pišući u brojnim listovima i objavljujući nekoliko značajnih knjiga o crnogorskom pitanju, koje su došle na udar državne cenzure. Naime, on je od pristaše velikosrpske ideje u vrijeme crnogorskog ustanka 1919. evoluirao u crnogorskog nacionalnog ideologa, koji se zalagao za crnogorsku posebnost u odnosu na srpstvo. U sukobu na ljevici oko socijalne literature okrenuo se od svojih zemljaka Crnogoraca i priklonio Krleži, što je vodilo njegovu izbacivanju iz Komunističke partije. Nakon proglašenja NDH, surađuje s ustaškim vlastima organizirajući Crnogorski nacionalni komitet u Zagrebu. Godine 1942. uključuje se u organizaciju Hrvatske Pravoslavne Crkve i svojim tekstovima pokušava dati podlogu njezinoj konstituciji. U Zagrebu je u ratu posebnu pažnju poklonio genezi srpskog i crnogorskog komunizma. Završetkom rata, Sovjeti ga uhićuju u bijegu iz Hrvatske kod Graza i otpremaju u sibirski logor. Tamo je proveo deset godina, nakon kojih se vraća u Hrvatsku, gdje je osuđen na osam godina Golog otoka, ali je pušten nakon četiri godine odsluženja kazne 1959. Tada se zapošljava u Leksikografskom zavodu uz preporuku starog znanca Miroslava Krleže. Umro je u Zagrebu 1971. Danilo RADojević, Savić Marković Štedimlija o Crnoj Gori i Njegošu njegova vremena, Lingua Montenegrina, sv. 15, Podgorica 2015., 143 - 144. 
živopisne biografije, koji je u međuraću prešao ideološke rute od poslijeratnog crnogorskog „,bjelaša“, preko komunista, do crnogorskog nacionalista, a u samom je ratu bio predsjednik Crnogorskog nacionalnog komiteta u Zagrebu i blizak vlastima hrvatske države oko Pavelića. S obzirom na to da je bio Crnogorac koji je živio i djelovao u Zagrebu i da je bolje od ostalih poznavao posebnost srpskocrnogorskih veza i da su u početku rata Srbi i Crnogorci koji su se u ono doba u velikoj većini smatrali Srbima bili kralježnica četništva i partizanstva, Štedimlija se nametao kao glas autoriteta u pitanjima fenomena četništva i partizanstva u Drugom svjetskom ratu. Naravno, njegova razmišljanja o tim fenomenima iziskivala su vrijednosna opredjeljenja u promatranju ratnih zbivanja, a to su u prvom redu negativan odnos spram srpstva, jugoslavenstva i komunizma. Takav njegov stav tijekom rata rezultirao je priklanjanju idejama crnogorske i hrvatske nacionalne samostalnosti, ideja koje su se 1918. po shvaćanjima tadašnjih hrvatskih i crnogorskih političkih i intelektualnih elita trebale žrtvovati za više ciljeve zajedničkog jugoslavenskog suživota.

Područje današnje Crne Gore poslije razbijanja stare Jugoslavije 1941. bilo je teritorijalno razdijeljeno na tri dijela. Područje Boke Kotorske na jugozapadu izravno je uvučeno u talijansku državu i pripojeno talijanskoj Dalmaciji. Područja Ulcinja, Tuzi, Plava, Gusinja i Rožaja smještena na istočnim rubovima Crne Gore i naseljenima albanskim i muslimanskim stanovništvom pripala su Albaniji koja je bila također pod protektoratom Mussolinijeve Italije. Na preostalom području Crne Gore talijanski su fašisti uz pomoć dijela članova predratne Crnogorske federalističke stranke pokušali 1941. obnoviti nezavisnu crnogorsku državu. Dogodilo se to na Petrovdan 12. srpnja, kada je skupština sastavljena od 62 delegata proglasila „suverenu i nezavisnu crnogorsku državu“. Dan kasnije crnogorski su komunisti podigli ustanak protiv talijanskih vlasti i crnogorskih independista na preostalom teritoriju koji nije ušao u sastav Velike Albanije i Italije. ${ }^{4}$

Štedimlija je pozdravio događaje proglašenja nezavisne crnogorske države pod talijanskom zaštitom i blisko surađivao s krugom crnogorskih independista i njihovoj borbi protiv komunista i partizanskog pokreta u Crnoj Gori. Stanje od 1918. za Hrvatsku i Crnu Goru označio je vremenom „srpske okupacije koja je neprekidno trajala do sloma Jugoslavije“. Postavljanjem hrvatskog i crnogorskog pitanja u središte nepovratno je značilo bojkot izgradnje zajedničke jugoslavenske nacije i odbacivanje eventualne obnove poslijeratne jugoslavenske državnosti. ${ }^{5}$

Živko ANDrijašEvić, Šefko RAStoder, Istorija Crne Gore, Podgorica, 2006., 407 - 408.

Savić MAR Ković ŠTedimliJa, Crnogorsko pitanje, Zagreb, 1941., 3 - 4. 
Stoga je Štedimlija razdoblje nakon 1941. i raspada Kraljevine Jugoslavije okarakterizirao na način da se od tada „iz temelja ispravljaju sve versailleske nepravde, a Crna Gora je uvjerena da će doživjeti puni trijumf pravde i ponovno uskrsnuti u društvu slobodnih država i prosvijećenih naroda“. 6

Ovu novu situaciju o potrebi suradnje Crne Gore i hrvatske države opravdavao je tako što je posegnuo u daleku prošlost. Pišući o Popu Dukljaninu, spominjao je srednjovjekovni savez Hrvatske i Duklje te osobito isticao određenu ulogu hrvatskog elementa u etnogenezi modernih Crnogoraca jer je srednjovjekovna Crna Gora bila prema zapisima Popa Dukljanina "Crvena Hrvatska“.7 O tome svemu Štedimlija je u svom djelu „Crvena Hrvatska“ pisao da su „u svoju današnju zemlju, Crnogorci došli kao Hrvati i pod tim imenom živjeli nekoliko vjekova, a tek kasnije kad je bila srednjovjekovna srpska država, u čiji je sastav ušla predhodnica današnje Crne Gore Zeta, počela je pod uticajem i pritiskom autoriteta nove države da se gubi hrvatska u korist srpske nacionalne svijesti kod predaka današnjih Crnogoraca“" ${ }^{8}$

Utjecaj hrvatskih povjesničara među kojima se isticao Milan Šufflay na ovakve Štedimlijine teorije o podrijetlu Crnogoraca i Crvenoj Hrvatskoj dokumentiran je brojnim pozivanjem na toga pisca u njegovim djelima o istoj tematici. ${ }^{9}$ Štedimlija je još u vrijeme Kraljevine Jugoslavije doživljavao napade velikosrpskih autora poradi spomena hrvatskog udjela u crnogorskoj etnogenezi jer su ovi strahovali da takva povijesna argumentacija ne bi potegla zahtjev za hrvatsko povijesno pravo na Crnu Goru. Međutim, Štedimlija se ograđivao od takvih napada, odbacujući bilo kakve aluzije da bi njegovo pisanje imalo implikacije po kojima su tadašnji Crnogorci Hrvati ili da bi to mogli postati i prihvatiti hrvatski identitet. ${ }^{10}$ Ako je Štedimlijino razmatranje o postanku crnogorske nacije imalo neke političke ciljeve, onda je to zasigurno nastojanje da se povežu crnogorsko i hrvatsko

6 S. M. ŠTEdimlija, Crnogorsko pitanje, 20.

7 Savić Marković ŠTedimlija, Tragom popa Dukljanina, Zagreb, 1941.

8 Ta je knjiga bila zabranjena od državne cenzure, kao i drugi tekstovi koje je Štedimlija objavljivao u zagrebačkom Obzoru na tu temu: S. M. ŠTedimlijA, Crvena Hrvatska (1937.), Split 1991., 9. Danilo Radojević napisao je predgovor izdanju triju Štedimlijinih zabranjenih knjiga u kojima je analizirao njegovo pisanje o crnogorskoj etnogenezi. Autor osporava Štedimlijinu tezu da Crnogorci nemaju autohtonu etničku osnovu. Što znači da ne pripadaju etničkom stablu ni Srba, kako su tvrdili velikosrpski autori i unitarno orijentirani komunisti, ali ni Hrvata kao što je tvrdio Štedimlija. Danilo Radojević, Tri zabranjene knjige Savića Markovića Štedimlije: Gorštačka krv, Crna Gora u Jugoslaviji, Osnovi crnogorskog nacionalizma, Podgorica 2008., 40.

$9 \quad$ S. M. Štedimlija, Crvena Hrvatska, $30-31$.

10 D. Radojević, Tri zabranjene knjige Savića Markovića Štedimlije..., 43. Radojević ukazuje na te napade na Štedimlijina djela Crna Gora u Jugoslaviji 1936. i Osnove crnogorskog nacionalizma 1937. koje su se obje našle na udaru ne samo u raspravama velikosrpskih autora nego i državne cenzure. 
nacionalno pitanje, kako bi u ojačanom zajedničkom bloku nastupali protiv jugoslavenskog unitarizma i velikosrpskog nacionalizma. To je bila u glavnim obrisima osnovica njegova intelektualnog angažmana u vodama politike.

Veliki broj njegovih Crnogoraca u partizanskom pokretu na području NDH pobuđivao je Štedimlijino zanimanje. Kao dobar poznavatelj crnogorskih prilika u međuraću, iznio je u tom pogledu neke detalje vezane za slučaj „crnogorskog komunizma"."11 Protežiranje Karađorđevićeva režima s ciljem školovanja na beogradskom sveučilištu potomaka crnogorskih „bjelaša“, velikosrpske struje u Crnoj Gori koja je odnijela prevagu u događajima oko Podgoričke skupštine 1918. i brisanju dugogodišnje državnosti Crne Gore, imalo je slomiti crnogorski otpor beogradskom centralizmu. Po Štedimlijinu mišljenju, njihovi potomci, poput Milovana Đilasa, školujući se na beogradskom sveučilištu nisu mogli prihvatiti velikosrpstvo svojih očeva, ali ni za njih prijezira vrijednu borbu crnogorskih nacionalista, tako da su se zaputili pravcem Marxove filozofije. ${ }^{12}$ Među crnogorskim komunistima našla se i druga struja, sinova iz „zelenaških“ obitelji, poput Svetozara Vukmanovića ${ }^{13}$ ili Jova Kapičića ${ }^{14}$. Iako su im marksizam i partijski jugoslavenski nacionalizam otupili nacionalnu oštricu tako da više nisu mogli koračati političkim putovima svojih otaca i nastaviti utirati staze crnogorskog odvajanja od srpstva, $\mathrm{u}$ partijskom nacionalnom programu emancipacije crnogorske nacije uvidjeli su šansu da se crnogorstvo afirmira $\mathrm{u}$ jugoslavenskoj državi i da se ista preoblikuje iz unitarne u federalnu državu. Štedimlija iako je za to sve znao, nije htio vjerovati da je prodor komunističke ideologije u mladu crnogorsku inteligenciju toliko snažan da je uspostava crnogorske državnosti u Drugom svjetskom ratu nemoguća misija. Stoga je skupa sa svojim istomišljenikom Drljevićem težio pošto-poto za ostvarenjem crnogorske

11 S. M. ŠTEDIMLIJA, Školovanje crnogorske omladine, Zagreb, 1936.

12 S. M. Štedimlija, Partizani o sebi, Zagreb, 1944, 79.

13 Svetozar Vukmanović zvani Tempo rodio se u selu Podgor kod Cetinja 1912. Kao student beogradskog pravnog fakulteta aktivno se priključuje komunističkom pokretu. U ratu je bio nositelj visokih vojnih i operativnih dužnosti u Narodnooslobodilačkom pokretu. Nakon rata bio je jedno vrijeme ministar rudarstva FNRJ, član Centralnog komiteta i predsjednik Saveza sindikata Jugoslavije te nositelj drugih visokih političkih dužnosti u Titovoj Jugoslaviji. Napisao je memoare 1971. u kojima je progovorio o sudbini svoje obitelji i progonima svoga oca nakon ulaska srpskih vojnih snaga u Crnu Goru. Umro je 2000. godine.

14 Jovo Kapičić rodio se 1919. godine u Italiji u Gaeti gdje je njegova obitelj našla utočište nakon propasti crnogorske države i neuspjelog Božićnog ustanka. Još za gimnazijskih dana na Cetinju priključio se komunističkoj organizaciji. Bio je jedan od predvodnika "trinaestojulskog ustanka“ 1941. u Crnoj Gori. Nakon rata kao visoki dužnosnik tajne policije bio je organizator lova na Dražu Mihailovića i Krstu Zrnova Popovića. Zatim je bio zamjenik ministra unutarnjih poslova Aleksandra Rankovića i kao takav organizator logora Golog otoka i hapšenja informbiroovaca. Od 1980-ih bio je neprijatelj Miloševićeve politike i pobornik crnogorske nezavisnosti. Umro je 2013. 
državnosti, pa makar i uz pomoć vanjske talijanske sile u okolnostima iznutra podijeljene Crne Gore, što se ubrzo pokazalo njihovom političkom zabludom.

S ovakvih je stajališta Štedimlija započeo vrednovanje političkih i ideoloških fenomena partizanstva i četništva, koji su se u ratnoj drami borili za pobjedu jugoslavenske ideje, nudeći u tome doduše istoznačan oblik, ali bitno drugačiji sadržaj „Nove Jugoslavije“. Revolucionarna i socijalistička ideja buduće Jugoslavije nasuprot konzervativnoj i monarhističkoj ideji Jugoslavije dovela je do prekida suradnje i neprijateljstava između Tita i Mihailovića krajem 1941. godine, odnosno između partizanskog i četničkog pokreta. Četnički pokret, koji se založio za zaštitu monarhističkih i konzervativnih vrijednosti srpske političke tradicije, već je 30. lipnja 1941. u Nikšiću izašao s ratnim memorandumom pod naslovom Homogena Srbija koji je potpisao banjalučki odvjetnik te član Nacionalnog komiteta Stevan Moljević. Sam cilj ovog memoranduma bio je „stvoriti Veliku Jugoslaviju i u njoj Veliku Srbiju“.15

Štedimlija je o tim tendencijama pisao tako da je tvrdio da se „po svoj prilici i jedni i drugi bore za uspostavu bivše Jugoslavije, samo bi po jednima trebala biti drugi sovjetski raj, a po drugima proširena velika Srbija “. ${ }^{16}$ Štedimlija je ovo pisao nakon održavanja zasjedanja AVNOJ-a u Jajcu u studenom 1943. i Svetosavskog kongresa u selu Ba u siječnju 1944., na kojem su se okupile pristaše Draže Mihailovića. U tim okupljanjima Titova i Mihailovićeva pokreta Štedimlija je naglašavao njihov poziv na obnovom Jugoslavije, ali s bitno različitim sadržajima koji su se sukobljavali oko oprečnih viđenja Jugoslavije kao „sovjetskog raja“ i Jugoslavije kao „proširene Velike Srbije“. Zbog svojih političkih stavova o hrvatskoj i crnogorskoj samostalnosti postao je žrtvom procesa pred sudom komunističke Jugoslavije tek 1955. godine, premda je optužnica podignuta deset godina ranije. Sudbina mu je nakon rata donijela pad u sovjetsko zarobljeništvo nadomak Graza. Odatle su ga Sovjeti deportirali u sibirske logore, odakle se vraća malo prije Hruščovljeva posjeta Titu 1955. godine. U Štedimlijinom dosjeu pisanom na nešto više od četiristo stranica sastavljenih na temelju njegova ispitivanja Službe državne sigurnosti nisam mogao pronaći razlog njegova izručenja Jugoslaviji, ali se čini da je bio žrtva zatopljenja odnosa između sovjetskih i jugoslavenskih vlasti. Njegovo izručenje je palo mjesec i pol dana prije Hruščovljeva posjeta Beogradu, koji je trajao od 27. 5. do 2.6.1955. ${ }^{17}$

\footnotetext{
Jozo Tom ASevich, Četnici u drugom svjetskom ratu, Zagreb, 1979., 155 - 156.

S. M. Š Tedimlija, Partizani o sebi, 105.

17 Hrvatska (dalje: HR) - Hrvatski državni arhiv (dalje: HDA), fond 1561 - Služba državne sigurnosti (dalje: SDS), Zapisnik sa slušanja Štedimlije 1955., kut. 45. Inače, njegova su sjećanja o životu u sibirskim logorima objavljena u: S. M. ŠTEDimLija, Deset godina u gulagu, Podgorica, 2004.
} 
Jugoslavenske komunističke vlasti su ga 1955. osudile na kaznu strogog zatvora od osam godina, ali je pušten nakon četiri godine izdržavanja kazne na Golom otoku godine 1959. Iza toga se zaposlio preko veza s Miroslavom Krležom u Leksikografskom Zavodu u Zagrebu. U presudi Saviću Markoviću Štedimliji među dva glavna krimena doslovno se navodi da je „od osnivanja NDH pa u celom toku okupacije razvijao vrlo opsežnu publicističku delatnost, provodeći kroz nju ustašku tezu, da je partizanski pokret velikosrpska zavera protiv Hrvatske države“ te što je zagovarao „samostalnu državu Crnu Goru“. Na sudu mu je branitelj bio zagrebački odvjetnik Ivo Politeo, a tekst presude pisan je ekavicom, dok mu se sudilo u Zagrebu. Štedimlija „osudjuje se na kaznu strogog zatvora od osam godina u koju kaznu mu se ima uračunati vreme u pritvoru i istražnom zatvoru od 14. IV. 1955. godine“. Jedan od ključnih svjedoka optužbe za njegov rad u vrijeme rata bio je sociolog Mirko Kus Nikolajev, koji je jedno vrijeme prije rata bio aktivan član međuratnog jugoslavenskog komunističkog pokreta. ${ }^{18}$

\section{POVIJESNE VEZE SOCIJALIZMA, MARKSIZMA I VELIKOSRPSKOG NACIONALIZMA}

Štedimlija se nije zaustavljao na površinskim ratnim prilikama, nego se vraćao u prošlost kako bi došao do korijena veza između socijalističkih ideja i velikosrpskog nacionalizma. Tako su njihove stare povijesne veze bile pogodan čimbenik u pripremi srpskog nacionalnog duha za komunistički pokret. Premda je u Sarajevskom atentatu iz 1914. Štedimlija vidio „pucanj u svjetski mir“ koji je izveo „savez marksističkog socijalizma i velikosrbskog nacionalizma“, atentatori su ipak bili pod utjecajem različitih socijalističkih tradicija, pa i anarhizma, ali ne jedino i samo marksističkog pravca socijalizma. Sarajevski su atentatori svi redom bili članovi socijalističkog pokreta i članovi organizacije Mlada Bosna ${ }^{19}$ i u uskoj vezi s velikosrpskom tajnom organizacijom „Crna Ruka“. ${ }^{20}$ Ta se tajna organizacija zasnovala iz redova srpskih vojnih krugova koji su 1903. svrgnuli dinastiju Obrenovića i doveli na vlast drugu srpsku dinastiju, Karađorđeviće.

18 HR-HDA-1561-SDS, Presuda Okružnog suda Zagreb, br. 53/56-18, Presuda Okružnog suda Zagreb KO. 53/56-18, kut. 45., 429., 436.-437.

19 I Redžić kao i Štedimlija naglašava evidentan utjecaj različitih socijalističkih tradicija, austromarksista, boljševika, esera, anarhista na Mladobosance „Černiševski, Bakunjin, Marks, Bebel, Kaucki itd..... Enver ReDžıć, Mlada Bosna u interpretaciji Veselina Masleše, u: Veselin MASlešA, Mlada Bosna, (II. izdanje), Sarajevo, 1990., 17.

20 S. M. ŠTEdimlija, Crna ruka i partizani, Spremnost (Zagreb), 16. 5. 1943., 3. 
Nakon što je vlada Kraljevine Srbije na čelu s radikalima i kraljem Petrom priznala Austro-Ugarsku aneksiju Bosne i Hercegovine 1908., pretvaraju se u neprijatelje radikalske i kraljevske vlasti te počinju s raznim aktivnostima na području Crne Gore, Bosne i Hercegovine i Makedonije kako bi se putem organiziranog terora stvorila velikosrpska država na tom prostoru. Iz toga se nametnuo kao njihov poklič „Ujedinjenje ili smrt“. Ubojstva Franje Ferdinanda i veze s Mladom Bosnom i sarajevskim atentatorima te pokušaj ubojstva crnogorskog kralja Nikole u Bombaškoj aferi 1908. godine vanjski su izraz te i tako zamišljene političke djelatnosti Crne ruke. ${ }^{21}$

Suradnja između tajne organizacije "Crna Ruka“ i socijalista mladobosanaca u Bosni, koji se u ogromnoj većini bili Srbi, započela je nakon aneksije Bosne i Hercegovine 1908. Kako se nije mogla registrirati stranka velikosrpskog programa, pribjeglo se osnutku stranke socijaldemokrata u Bosni i Hercegovini, i to na Vidovdan 1909. kako bi se preko nje tajno vršila velikosrpska propaganda, i to ne samo među Srbima nego i među Hrvatima i muslimanima. ${ }^{22}$ Tako se kosovska mitologija povezala sa srpskim socijalizmom i dala mu jaki nacionalistički predznak. Osnivač i vođa "Mlade Bosne“ Vladimir Gaćinović bio je raspoložen za velikosrpsku ideologiju, za pripojenje Bosne i Hercegovine Kraljevini Srbiji. Za vrijeme studija u Švicarskoj družio se s ruskim revolucionarnim krugovima, a na poseban način s ruskim eserima, prihvaćajući njihovu ideologiju socijalizma i revolucije. ${ }^{23}$ Zajednički cilj Mlade Bosne i Gaćinovića te tajne organizacije Crna Ruka 1914. bio je uništenje Monarhije i širenje srpske države na zapadne strane. U pripremama oko atentata na prijestolonasljednika Franju Ferdinanda Štedimlija je dokazivao veze organizatora sarajevskog atentata Vladimira Gaćinovića, Danila Ilića i Nedeljka Čabrinovića s Trockim i Lenjinom. ${ }^{24}$ Kod policijske kontrole članova

21 O njihovu djelovanju i organizaciji vidi više: Radovan M. Draš Ković, Pretorijanske težnje u Srbiji - Apis i Crna ruka, Beograd, 2006.

22 S. M. ŠTedimlija, Podrietlo srbskog komunizma, Spremnost (Zagreb), 13. 2. 1944., 7.

23 Radoslav Gaćinović, Mlada Bosna - uloga i značaj Vladimir Gaćinovića, Beograd $2014 ., 222$ - 223, 237. U drugoj Jugoslaviji posebno se isticalo jugoslavenstvo Mlade Bosne i njihov tobože jugoslavenski patriotizam, međutim, kako ističe Radoslav Gaćinović, „njezin glavni ideolog Vladimir Gaćinović nije nimalo bio sentimentalan prema ideji jugoslovenstva i na nju je gledao kao na „mešanje hrvatske vode u srpsko vino“.

24 Gaćinović se za vrijeme svoga bijega iz Bosne zbog protuaustrijske djelatnosti upoznao u Švicarskoj i Francuskoj među brojnim ruskim socijalistima i anarhistima i s Lenjinom i Trockim, koji je kako je kasnije tvrdio Đilas, da tada on nije razumio Gaćinovićevu težnju za srpskom nacionalnom revolucijom u austrijskoj Bosni. Ova knjiga odmah je kod objave odmah došla na udar cenzure kraljevskog režima, tako je da je bila prava rijetkost. Milovan ĐilAs, Lik Vladimira Gaćinovića, Današnjica i Mlada Bosna: uloga i značaj Vladimira Gaćinovića (1937.), Banja Luka 2014., 14 - 15. 
Mlade Bosne nakon Sarajevskog atentata nađene su „knjige i brošure Marksa, Bakunjina, Krapotkina, Bebela, Kauckoga, Stepnjaka itd.“ ${ }^{25}$

Isto tako su i partizanske i četničke brigade nosile ime Gavrila Principa, a Masleša i Đilas, partizanski vođe, u Gaćinoviću su vidjeli marksističkog revolucionara koji je podržavao odnose s ruskim boljševicima. Masleša je također i o Mladoj Bosni napisao 1940. značajnu povijesnu studiju, koja je posthumno objavljena 1945. godine. ${ }^{26}$ Pisana je tridesetih godina i u njoj je Masleša negirao jugoslavenski karakter Mlade Bosne što je bila intencija historiografija obiju Jugoslaviju, zato kaže da „iako je kasnije prešla na jugoslavenske pozicije, nije nikada mogla da pređe preko teze o Bosni kao srpskoj zemlji, iakoje jedan deo (vrlo mali) hrvatske omladine pristupio Mladoj Bosni i bio jugoslavenski orijentiran“. Masleša dalje izlaže da je „interesantno da mnogi pisci, koji su posle rata (op. a. Prvog svjetskog rata) ostali na tzv. jugoslavenskoj liniji, govoreći o Mladoj Bosni naročito podvlače učešće Hrvata u njoj, nabrajujući i imenujući sve ličnosti koje su uzele ma kakvog udjela u njenom radu. Već samo ovo preterano naglašavanje je simptomatično i znači da se time želi ustvrditi 'jugoslavenska’ struktura Mlade Bosne, koju ova stvarno nije imala. “27 Iz duhovne ostavštine Mlade Bosne nakon 1918. godine po Masleši su se razvile dvije struje srpske politike, jedna koja se okrenula društvenom konzervativizmu i druga koja se okrenula idejama revolucije i radikalne preobrazbe društva. $U$ tom dinamičnom odnosu odigravao se sukob između republikanizma i monarhizma, koji je obilježio srpsku političku pozornicu prve polovine 20. stoljeća. ${ }^{28}$

Štedimlijino povezivanje tajne $\mathrm{i}$ terorističke organizacije Crna ruka i partizana, na duhovnoj i simboličnoj razini, nije bila obična propagandna dezinformacija. Put prema konačnoj rehabilitaciji Apisa i drugova već se nazirao objavom neobjavljenog dokumenta o njihovu suđenju u Beogradu $u$ studenom 1944. godine, u kojem se posebno naglašavaju Apisove posljednje riječi prije pogubljenja: „živela Velika Srbija i živela Jugoslavija“. ${ }^{29}$ Apis i Crna

25 Danilo Ilić prevodio je djela ruskih anarhista i revolucionara Bakunjina, Andrejeva i Gorkog, a Čabrinović je obilno čitao anarhističku i socijalističku literaturu. Gaćinović je nakon odlaska u Lausanneu na studije pridodao svom srpskom nacionalizmu socijalistička i marksistička uvjerenja. Vidi: Veselin MAslešA, Mlada Bosna (1945.), (II. izdanje), Sarajevo, 1990., 166.

26 V. MAslešA, Mlada Bosna, (I. izdanje), Beograd 1945., 5. Pisac predgovora prvog izdanja bio je Milovan Đilas. Spominje da je rukopis okončan godine 1940. i da ga je Masleša dao beogradskom odvjetniku Miši Pavloviću na čuvanje.

27 V. MAsleša, Mlada Bosna, (II. izdanje), 169.

28 V. MAslešA, Mlada Bosna, (II. izdanje), 187 - 199. Na to je skrenuo pažnju Masleša na kraju svoje knjige o Mladoj Bosni u poglavlju „Gde bi bili danas“.

29 Ovaj dotada nepoznati dokument o Apisu i drugovima izašao je u beogradskoj Politici samo godinu i nekoliko mjeseci nakon Štedimlijina teksta u Spremnosti. Neobjavljen dokument o strijeljanju pukovnika Apisa i drugova, Politika (Beograd), 26. 10. 1944., 5. 
Ruka predstavljali su duhovne pretke partizanske pobune protiv dinastije Karađorđevića. Njegove posljednje riječi objavljene na stranicama beogradske Politike mjesec dana poslije ulaska partizana u Beograd bile su potvrda da borba protiv dinastije Karađorđevića nipošto ne znači da time Apisovi nasljednici, srpski komunisti, izdaju ideale srpstva i Jugoslavije. Komunisti su poslije rata na inicijativu Aleksandra Rankovića 1953. godine i službeno rehabilitirali Dimitrijevića Apisa, Radu Malobabića i Ljubu Vulovića te ostale članove Crne ruke koji su stradali na Solunskom procesu $1917 . .^{30} \mathrm{U}$ njihovom listu Pijemont pisao je kao njihov pripadnik i novinar jedan od glavnih poslijeratnih srpskih komunista Moša Pijade (1890. - 1957.). ${ }^{31}$

Prema Štedimliji, ciljevi partizanskog pokreta ne napuštaju velikosrpski program star gotovo jedno stoljeće. Premda su se jugoslavenski komunisti, koji su u velikoj većini bili i sami Srbi, stavili na kormilo toga pokreta, morali su usvojiti Garašaninov plan Velike Srbije iz 1844., kako bi uopće došli u priliku da upravljaju tim pokretom i da on naiđe na pozitivan odjek u srpskom narodu. Štedimlija je zastupao mišljenje da postoji čitav lanac povezanih događanja u dugom vremenskom razdoblju koji su svjedočili o dugovječnosti velikosrpske politike. Od Garašaninova plana koji je označio rođenje takve politike, prevrata 1903. i svrgavanja dinastije Obrenović, sarajevskog atentata 1914. i Simovićeva puča od 27. ožujka 1941. do Antifašističkog vijeća narodnog oslobođenja Jugoslavije (AVNOJ) u Bihaću 1942., svi oni odražavaju planove i ciljeve stoljetne velikosrpske politike. ${ }^{32}$

Slijedom toga držao je da su „Načertanije“ ministra unutarnjih poslova Kneževine Srbije iz 1844. manifest „zavjereničke velikosrpske politike“, koja je postala „planom Srbije za budućnost“. Ista je kumovala pri državnom udaru 27. ožujka 1941. kojom je izvršeno „samoubojstvo Jugoslavije“, tako da je i Jugoslavija tijekom svoga dvadesetogodišnjeg života bila ništa drugo nego alat „, rukama takve zavjereničke politike“. ${ }^{33}$ Mišljenje Štedimlije je takvo da je govor o jugoslavenstvu koje je AVNOJ širio na područjima NDH pokušaj da se pridobiju

30 Tom događaju je posvećena i knjiga koja je izašla u sjeni rehabilitacije Apisa i drugova: Borivoj NEŠKović, Istina o solunskom procesu, Beograd, 1953.

31 Dušan T. Bata ković, Serbian War Aims and Military Strategies (1914-1918), The Purpose of the First World War: War Aims and Military Strategies, (ed. Holger Afflerbach), Berlin/Boston 2015., 80.

32 S. M. ŠTEDimlija, 40 godina srpske politike, Spremnost (Zagreb), 30. V. 1943., 6.

33 S. M. ŠTedimlija, Zavjere protiv svjetskog mira, Zagreb, 1944., 49 - 65. U poglavlju „Politički program Srbije“ Štedimlija je u Garašaninovoj ideji razradio smjernice velikosrpskog programa. Prvi svezak knjige izdan 1944. pokrivao je vrijeme od 1844. do 1914. godine, a drugi, koji je trebao pokrivati razdoblje od 1914. do 1944,. nikada nije bio objavljen. 
Hrvati, ali i drugi narodi na područjima bivše Jugoslavije, kako bi se spasila velikosrpska ideja. Širenje jugoslavenskog nacionalizma zato je samo nastavak velikosrpske politike koja se odvijala na isti način za dinastije Karađorđevića, kada se propagirao u onim krajevima gdje nisu živjeli etnički Srbi ili gdje nisu imali dominantnu većinu. Sve svoje vizije o stoljetnoj velikosrpskoj politici, njezinim načelima, ciljevima i žilavosti usprkos protoku vremena najpotpunije je razvio u svom djelu na njemačkom jeziku iz 1944. godine pod naslovom Verschwörungen gegen den Frieden. ${ }^{34}$

Zasigurno jedna od središnjih Štedimlijinih opservacija je ona da se „četničko-komunistički ustanak“ prelio u ljeto 1941. iz svojih epicentara u Srbiji i Crnoj Gori na područja NDH. Time je želio opovrgnuti da je taj pokret nikao na teritorijima novouspostavljene $\mathrm{NDH}$, i da je prebacivanje borbe partizana $\mathrm{i}$ četnika iz Srbije i Crne Gore u NDH nakon 1941. zapravo „dokaz za urotu protiv novonastale hrvatske države“. ${ }^{35}$ Gledajući na partizane i četnike iz perspektive njihove otvorene opasnosti za opstanak NDH, ni nakon 1942., kada je došlo do pucanja četničko-partizanske suradnje ${ }^{36}$ i do otvorenih sukoba među njima, nije držao presudnim njihovo ideološko razmimoilaženje. I dalje je branio tezu o povezanosti „marksizma i velikosrpstva“ vidjevši u tome ne rascjep na idejnoj bazi nego sukob Tita i Mihailovića. ${ }^{37}$ Štedimlija je tako govorio da je nakon 1942. puknuo četničko-partizanski savez oko pitanja prvenstva u pokretu, spominjući neuspješne pregovore u Javoranama 21. prosinca 1941. Unatoč tomu događaju, smatrao je da je usprkos međusobnim proganjanjima četnika i partizana njihov zajednički neprijatelj hrvatska država. Stoga je naglašavao da „bi bila to nova grobnica hrvatskoga naroda kad bi se ostvarili planovi njihovih odmetničkih bandi i njihovih vlastodržaca iz Moskve i Londona“. ${ }^{38}$ Kada je riječ o samoj

34 S. M. ŠTEDImLiJA, Verschwörungen gegen den Frieden, I. tomus, Zagreb 1944.

35 S. M. ŠTEDIMLIJA, Zavjere protiv svjetskog mira, 124.

36 J. Tomasevich, Četnici u Drugom svjetskom ratu, 140. Tomasevich donosi podatke o susretu Mihajlovića i Tita 20. listopada 1941. u selu Brajići, zapadna Srbija, nakon koje nije usuglašena daljnja suradnja dviju grupacija, nego je došlo do otvorenih sukoba.

37 S. M. ŠTedimlija, Partizani o sebi, 102 - 103. Slična razmišljanja ponudio je i obavještajac iz redova HSS-a u pismima izbjegličkoj vladi u Londonu, kada je govorio slijedeće: „Tito ne može nikoga trpiti (...)Tito je radi toga otvorio borbu protiv Draža Mihailovića, jer je mislio da mu je on konkurent (...); Ljubo BoвAN, Izvještaj nepoznatog St. Jakšekoviću, početkom VI. mj. 1944., Hrvatska u diplomatskim izvještajima izbjegličke vlade 1941.-1943., Zagreb, 1988., 274. Suprotno ovomu mišljenju ponudio je Tomasevich, da je „najvažniji četnički razlog za odluku da se bore protiv partizana ležao u njihovoj krajnjoj opoziciji prema prirodi i ciljevim partizanskog pokreta“. J. Tomasevich, Četnici u Drugom svjetskom ratu, 145. Sabrina Ramet kaže da je inzistiranje britanske vlade da se Tito podvrgne Mihajloviću bilo neuspješno jer se ovaj oglušio na te pozive. Sabrina RAmet, Tri Jugoslavije-izgradnja države i izazovi legitimacije, Zagreb, 2009., 205.

38 S. M. ŠTEDIMLIJA, Zavjere protiv svjetskog mira, 102 - 105. 
završnici rata, Štedimlija je u profederalističkim deklaracijama AVNOJ-a od 29. studenog 1943. i Svetosavskog kongresa od 28. siječnja 1944. kao i političkom idejama Nedićeva Beograda o „srpskom životnom prostoru“ nazirao ugroženost cjelokupnog srpskog političkog spektra koje je svoj opstanak gradilo na „razbijanju integriteta NDH-a“.39

Razloge zašto Srbi masovno pristupaju partizanskom pokretu te se približavaju Komunističkoj partiji Jugoslavije tražio je Štedimlija u duhovnoj ostavštini trojice srpskih promicatelja socijalističkih ideja Svetozara Markovića, Vase Pelagića i Jovana Skerlića. Pri tome je osobito naglašavao snažne utjecaje ruskog socijalizma druge polovine 19. stoljeća na modernu srpsku inteligenciju. U ruskim vezama s ovim socijalističkim učiteljima pronalazio je "podrietlo srbskog komunizma“ koji se rađao u ratnom vihoru. Svetozar Marković unio je baklju socijalizma u Srbiju kada je 1871. osnovao prvi socijalistički list na Balkanu imenom Radenik. On je bio učenikom vodećih ruskih socijalista i revolucionara toga vremena poput Hercena, Dobroljubova i Černiševskog. Srpski povjesničar Vasa Čubrilović (1987. - 1990.) spominje Skerlićevo mišljenje da je na Markovića utjecao najviše Černiševski, jedan od glavnih ruskih socijalista. Nadalje, Čubrilović pojavu samog Markovića u srpskom devetnaestom stoljeću smatra „početkom izgradnje socijalističke misli u Srbiji“. Osim kritike građanske države kakva se podizala u Srbiji, Čubrilović navodi i strogo Markovićevo protivljenje monarhističkom uređenju. Sve te ideje kasnije su ponijeli i srpski partizani i komunisti u napadu na građansko društvo stare Jugoslavije i na njezin monarhistički ustroj. Osim toga, Marković je uz revoluciju vezao i rješenje nacionalnog pitanja, tako da se bez demokratizacije i micanja autoritarnog režima kojem dominiraju kralj, birokracija i vojska ne može doći do rješenja nacionalnog pitanja, koje se jedino može provesti kroz uvođenje socijalizma. ${ }^{40}$

K tomu je Marković bio otac srpskog realizma u književnosti koji je snažno utjecao na srpsku kulturu, tako da su se na njegovim djelima intelektualno oblikovali i vodeći srpski komunisti u ratu kao Veselin Masleša, koji se pred izbijanje rata spremao objaviti njegova sabrana djela. Marković je tako na neki način postao rodonačelnik srpskog lijevog nacionalizma u njegovim najranijim početcima. I u Crnoj Gori nakon boljševičke revolucije njezini sudionici rodom iz te zemlje šire komunističke ideje. Ona se najviše primila kod pravoslavnog stanovništva, gdje će i buknuti Trinaestojulski ustanak 1941., dok su albanski i muslimanski dijelovi Crne Gore ostavili van domašaja komunističke ideologije.

39 S. M. Š tedimlija, Podrietlo srbskog komunizma, 7.

40 Vaso Ču Brilović, Istorija političke misli u Srbiji XIX. veka, Beograd, 1982., 210, 233, 235. 
Tako kao sudionik „Crvenog Oktobra“ djeluje i Štedimlijin stric, liječnik i boljševik dr. Vukašin Marković koji je primjerice pridobio svog suplemenika iz Pipera za komuniste poznatog vođu crnogorskih partizana i jednog od najbližih Titovih suradnika Ivana Milutinovića, koji je poginuo na Dunavu 1944. ${ }^{41}$

Pod istim ruskim utjecajima Pelagić je širio Bosnom socijalističke ideje u drugoj polovini 19. stoljeća. Kao što je Marković bio prvi socijalist u Srbiji, tako je Pelagić bio prvi socijalist u Bosni i Hercegovini. O Markoviću i Pelagiću Masleša je napisao značajne studije nalazeći u njima nadahnuća za njegovo partijsko djelovanje i programe. ${ }^{42}$ Pelagić je kao pravoslavni arhimandrit svojim pisanjem i djelovanjem kao jedan od rijetko obrazovanih pravoslavnih svećenika ostavio ogroman utjecaj na Pravoslavnu crkvu u Hrvatskoj, Bosni i Hercegovini i Srbiji. Imao je veliki utjecaj na javno mišljenje i u Srbiji. Zbog socijalizma i podizanja buntovništva sud u Carigradu osudio ga je na 101 godinu zatvora. Nakon što je pobjegao iz zatvora, bavio se izdavačkim radom i objavljivao mnoga svoja djela u kojima je propovijedao socijalizam i socijalno buntovništvo. Navodno nije bilo kuće gdje nije bilo Pelagićeve knjige po pravoslavnim krajevima Srbije, Bosne i Hrvatske. Pelagićev kult revolucionara i marksista prihvatili su i komunisti, tako da je spomenuti Veselin Masleša kao srpski komunist iz Bosne 1940. ponovno izdao poznatu Pelagićevu knjigu Narodni učitelj.

U tome je Štedimlija vidio uzroke prilaženju srpskih pravoslavnih svećenika komunističkom pokretu u Bosni i Hrvatskoj, pojedinaca kao što su Vlada Zečević, vijećnik u predsjedništvu AVNOJ-a, član Vrhovnog štaba NOVJ i POJ, prota iz Krupnja. Jevstatije Karamatijević, vijećnik u predsjedništvu AVNOJ-a i član ZAVNO Sandžaka, prota iz Nove Varoši i Save Savić. ${ }^{43}$ Osim njih, Vojislav Kecmanović, iako nije bio prijeratni komunist, bio je prvi predsjednik Zemaljskog Antifašističkog Vijeća Narodnog oslobođenja $\mathrm{BiH}$, a potjecao je iz obitelji svećenika čiji su otac i brat bili pravoslavni svećenici. ${ }^{44}$ Samo se tako može razumjeti, ponavljao je Štedimlija, paradoks da „svećenici jedne kršćanske crkve pozivaju svoje vjernike i sumišljenike da se pridruže partizanima, koji kao komunisti ne priznaju nikakve, a najmanje kršćanske crkve“. ${ }^{45}$ Jovan Skerlić je početkom stoljeća bio simpatizer Srpske socijalističke stranke osnovane odmah

41 Pavle Ljumović, Ivan Milutinović Milutin, čovjek i ratnik, 2008, digitalno izdanje, posjećeno 12. 10. 2016., http://www.montenegrina.net/pages/pages1/istorija/cg_u_2_svj_ratu/pavle_ ljumovic_ivan_milutinovic_covjek_i_ratnik.htm

42 Enver ReDžıć, „Mlada Bosna u interpretaciji Veselina Masleše“, u: Veselin Masleša, Mlada Bosna, Sarajevo, (II. izdanje), 1990., 8.

43 S. M. ŠTedimlijA, Srbski pravoslavni svećenici i partizani, Spremnost (Zagreb), 23. 5. $1943 ., 8$.

44 Ivo Lučıć, Što je (bila) Bosna i Hercegovina i tko smo (bili) mi?, Status, sv. 14., Mostar $2010 ., 109$.

45 S. M. ŠTEdimlija, Srbski pravoslavni svećenici i partizani, 8. 
poslije uspona na prijestolje Petra I. Karađorđevića 1903. i gorljivi promicatelj Marxova učenja i veliki štovatelj lika i djela Svetozara Markovića. ${ }^{46} \mathrm{Njegov}$ utjecaj nije bio ograničen na srpski kulturni prostor, nego je svojim djelom utjecao i na Naprednu omladinu u hrvatskim krajevima. ${ }^{47}$

Štedimlija je problematizirao i prelazak vojnog krila srpske nacionalne elite u partizanski pokret pod vodstvom komunista, tvrdeći da „onako kao što je bilo nagriženo komunizmom srbsko pravoslavno svećenstvo isto je tako bio njime više nego li nagrižen i srbski častnički zbor". U vezi s tim, donio je podatak da je u siječnju 1943. s bosanske planine Grmeč „tridesetak častnika bivše jugoslavenske vojske koji se nalaze u štabovima partizanskih jedinica, uputilo poziv aktivnim oficirima, vojnim činovnicima i podoficirima bivše jugoslavenske vojske, da stupe u redove Narodno-oslobodilačke vojske Jugoslavije“. Taj proglas u kojem su potpisani vojni zapovjednici, gotovo redom svi Srbi, prema njegovu mišljenju pokazuje „da oni upravljaju sveukupnom djelatnošću partizanskih jedinica“ i da ti vojni vođe „nemaju nikakve veze ni po svojoj krvi i narodnosti, ni po svojoj političkoj opredijeljenosti sa Hrvatskom i Hrvatima“" ${ }^{8}$

Njihov savez s komunistima tumači tako što im je komunistički ustanak iz ljeta 1941. vratio nadu u obnovu Jugoslavije, zbog čega su mu ponudili vojno-operativnu potporu. A sve za to jer je „srbski častnički zbor bio uviek obuzet brigom za najviše probitke srbstva, a ako bi ti probitci bili ugroženi, svaki srbski častnik bio je pripreman pristati i uz boljševizam, samo da odkloni naslućenu opasnost“. ${ }^{49}$ Te tvrdnje ilustrira podulja lista imena kraljevskih časnika koji su dostigli najviše položaja u strukturi NOVJ/JA, počevši od samog načelnika Vrhovnog štaba Arse Jovanovića. Pod tim utjecajem dobar dio bivših jugoslavenskih časnika postaju partizanski kolovođe, kao na primjer Velimir Terzić, Petar Ćetković, Milutin Morača, Vladimir Knežević Volođa, Savo Orović i drugi.

Nadalje, pisao je da su osim crkvene i vojne elite srpskog naroda i njegove političke elite pokazivale da nisu imune na izazov partizansko-komunističkog

46 Jovan SKerLIĆ, Svetozar Marković, njegov život, rad i ideje, Beograd, 1910.

47 Mirjana Gross, Nacionalne ideje studentske omladine u Hrvatskoj uoči I. svjetskog rata, Historijski zbornik sv. 21-22., Zagreb, 1968-1969., 75 - 143.

48 S. M. ŠTedimlija, Partizani o sebi, 99 - 100. Na ovom mjestu Štedimlija donosi i njihov popis tih bivših kraljevskih časnika u redovima partizanske vojske: Savo Orović, Velimir Terzić, Petar Ćetković, Risto Perović, Branko Poljanac, Vojislav Djukić, Branko Obradović, Djuro Roganović, Ilija Pavlović, Mileta Djukić, Ljubo Vučković, Rade Hamović, Milovan Šaranović, Petar Radević, Miloje Milojević, Ratko Martinović, Momčilo Stanojlović, Vlado Knežević, Periša Grujić, Ljubiša Urošević, Momčilo Poleksić, Nikola Martinović i dr.

49 S. M. ŠTedimliJA, Srbski častnici i komunizam, Spremnost (Zagreb), 6. 6. 1943., 6. 
pokreta. Prilikom osnivanja Socijalističke partije Jugoslavije, koja će kasnije prerasti u Komunističku partiju Jugoslavije, na beogradskom kongresu 1919., njezinu jezgru činili su Srpska socijaldemokratska stranka i Socijaldemokratska stranka Bosna i Hercegovine osnovana 1909., koju su također predvodili Srbi. ${ }^{50}$ Izuzev toga, Zemljoradnička i Samostalna demokratska stranka koje su isto njegovale socijalističke ideje, imajući jaka uporišta u srpskim „prečanskim krajevima" opetovano su zahtijevali tijekom međuratnog razdoblja uspostavu diplomatskih odnosa sa SSSR-om. Upravo su se prvaci tih stranaka i njihovi pristaše našli na bihaćkom I. zasjedanju AVNOJ-a u studenom 1942. godine. Pred rat su pokazivali simpatije prema marksizmu i socijalizmu, ali kao takvi nisu bili prepoznati u političkom životu kao komunisti.

$\mathrm{Na}$ primjer, Zemljoradnička stranka kroz cijelo je međuraće zahtijevala uspostavu diplomatskih odnosa sa SSSR-om, a taj trud nagrađen je imenovanjem njihova stranačkog prvaka Milana Gavrilovića za poslanika Kraljevine Jugoslavije u Moskvi nakon što su 1940. bili uspostavljeni diplomatski odnosi između dviju zemalja. Izbjegavanje komunističkog nazivlja i ustrajanje u antifašističkom imenu partizansko-komunističkog pokreta imalo je dvostruku nakanu. $S$ jedne strane trebalo je po Štedimliji smekšati hrvatski narod za komunizam i s druge strane prikriti vodeću ulogu Komunističke partije Jugoslavije u organizaciji toga pokreta. Pravi karakter toga pokreta je taj da se „Antifašističko vieće bori za Veliku Srbiju koja bi bila podvrgnuta sovjetskom režimu, odnosno boljševizmu i crvenoj Rusiji.“ To je Štedimlija pisao u prvim mjesecima 1943. poslije zasjedanja I. AVNOJ-a u Bihaću za koji je s obzirom na nacionalni sastav, zaključivao da je „antifašističko vieće“ u svojoj biti „velikosrbska zajednica." ${ }^{\text {“s1 }} \mathrm{U}$ osvrtu na političko partizansko vodstvo poimence je nabrajao članove izvršnog odbora i vijeća bihaćke skupštine, u kojoj su prisutni u golemoj većini Srbi, a od ono

50 Njezini prvaci Dragoljub Gospić, Nedeljko Čabrinović, Andrija Ljubojević, Spasoje Lojpur, Dušan Pavić, Milan Dragović, braća Jakšići, Sreten i Jovo usko su surađivali sa srpskim socijaldemokratima. Tako je Mihajlo Mika Todorović tvrdio da su oni „održavali čvrste veze sa srbijanskim radničkim pokretom i njegovim vodećim ljudima, da nije isključeno da su oni kao Srbi bili orijentisani prema Srbiji, te da je verovatno (...) da su u tom smislu igrali i izvesnu ulogu van one u radničkom pokretu“. Babić spominje i dvije frakcije u stranci, jednu nacionalnu i drugu revolucionarnu. Za prvu kaže da je bila „značajnija i brojnija“ i da je bila sastavljena od Srba. Ta srpska frakcija došla je do izražaja od balkanskih ratova kada putem secesije žele ostvariti svoj program, tražeći pripojenje Bosne i Hercegovine Srbiji. Oni su bili protiv antiratne politike stranke i njezine nezainteresiranosti prema nacionalnom pitanju. Put te frakcije završio je priključenjem nacionalno-revolucionarnoj organizaciji Mlade Bosne. Nikola BABIĆ, Rat, revolucija i jugoslovensko pitanje u politici socijaldemokratske stranke Bosne i Hercegovine, Sarajevo, 1974., 135, 147, 159.

51 S. M. ŠTedimlija, Crna ruka i partizani, Spremnost (Zagreb), 16. 5. 1943., 8. 
malo Hrvata svi su bili simpatizeri lijeve misli ili otvoreni komunisti. ${ }^{52} \mathrm{Njih}$ sve odlikuje jedinstven stav tako da „između onog dijela partizanskog vodstva, koje ne skriva svoju pripadnost komunističkom pokretu i onog dijela čiji članovi nisu pripadali izravno komunističkim organizacijama, u odnosu prema Nezavisnoj Državi Hrvatskoj i hrvatskom narodu, nema zapravo nikakve razlike“.53

Doduše, prema Štedimlijinoj analizi izabrani predsjednik Ivan Ribar, koji je potjecao iz hrvatske sredine, uvijek se nalazio na strani unitarističkih politika, počeo je kao jugoslavenski nacionalist u Naprednoj omladini za vrijeme Prvog svjetskog rata, da bi potom kao osnivač i član Demokratske stranke bio jedan od arhitekata politike vidovdanskog režima u svojstvu predsjednika Ustavotvorne skupštine 1920. U drugoj polovini 1930-ih godina priključio se Narodnoj fronti i počeo surađivati s komunistima. Ribarova figura na neki je način svojom pojavom i političkom karijerom trebala prikriti izvorno srpsko i komunističko obilježje te joj dati naličje antifašističke, demokratske i jugoslavenske skupštine. Od 70 članova AVNOJ-a iz hrvatskih krajeva bili su Đuro Tiljak, Andrija Hebrang, Šime Balen, Vladimir Bakarić, Vicko Krstulović, Mladen Iveković, Pavao Gregorić, svi odreda komunisti, a Jurica Draušnik, Pavao Krce, Florijan Sučić i Branko Zlatarić bivši članovi HSS, i to njegova lijevog krila naklonjenog komunizmu. Ostali članovi bili su u golemoj većini od skoro 90 posto Srbi, pa i ti koji su bili židovskog i muslimanskog porijekla poput Moše Pijade i Avde Hume također su se izjašnjavali nacionalno Srbima. Tijekom rata je i sam Tito, vodeća osobnost partizanskog pokreta, u prosincu 1942. godine naglasio je da se „u redovima naše Narodnooslobodilačke vojske i partizanskih odreda Jugoslavije, od samog početka pa do danas, nalaze u ogromnoj većini baš Srbi“". ${ }^{4}$ Isto tako je jedan od ondašnjih glavnih komunista iz NDH Vladimir Bakarić isticao da je u vrijeme prvog zasjedanja AVNOJ-a narodnooslobodilački pokret bio „srpski pokret“, naglašavajući da tada među Hrvatima nije našao odaziva, „ako izuzmemo, Dalmaciju, Gorski kotar i

52 Vidi detaljan popis članova I. AVNOJ-a koji potvrđuju Štedimlijine navode: Spisak članova Antifašističkog veća Narodnog oslobođenja Jugoslavije, Bihaćka Republika - zbirka dokumenata, knj. 2., Bihać 1965., 227 - 230.

53 S. M. ŠTedimlija, Crna ruka i partizani, Spremnost (Zagreb), 16. 5. 1943., 8.

54 J. B. Tiтo, Nacionalno pitanje u Jugoslaviji u svjetlosti narodnooslobodilačke borbe, Proleter, decembar 1942., 121. Primjerice, od hrvatskih područja koje je Bakarić spomenuo Dalmacija, koja je slovila kao partizanska pokrajina, dala je na prvom zasjedanju AVNOJ-a samo dva vijećnika, a ostali partizanski krajevi Gorskog kotara i Hrvatskog primorja ni jednoga. Željko Karaula u svom članku tvrdi da bi srpsko obilježje AVNOJ-a i partizanskog pokreta bila puka propagandna floskula medijske scene $\mathrm{NDH}$, iako i vodeći protagonisti partizanskog pokreta do 1943. govore o jakoj i dominantnoj srpskoj ulozi u njima. Željko KARAula, Pogled ustaških medija prema partizanskim zasjedanjima „srpskog“AVNOJ-a, Historijska traganja, sv. 6., br. 12., Sarajevo 2013., 141 - 154. 
Hrvatsko primorje“.55 I "oslobođeni teritorij" koji se formirao do I. zasjedanja AVNOJ-a u studenom 1942. obuhvaćao je područja naseljena većinski naseljena srpskim stanovništvom, a to su Zapadna Bosna i područja Like, Korduna, Banije te dijelove Slavonije gdje su živjeli Srbi. ${ }^{56}$

Štedimliji je mlada srpska inteligencija koja se podizala na beogradskom sveučilištu desetljeće prije rata bila osvojena od marksizma. Beogradsko sveučilište bilo je glavnim uporištem komunističke propagande u propaloj Kraljevini Jugoslaviji iz koje su izniknuli mladi srpski komunisti, koji će kasnije u ratu organizirati partizanski pokret. Tako su se prema Štedimliji od beogradskih sveučilištaraca „novačili svi prvaci partizanskog pokreta.“ Uspostavom diktature 6. siječnja 1929. začeli su se novi procesi koji su omogućili silan uzlet komunističke propagande, poznate pod nazivom tzv. socijalna literatura koja će preplaviti kulturnu scenu i književnost posebno. Kako je diktatura silom ugušila javni govor o nacionalnim pitanjima, držeći da su „separatistički i plemenski pokreti“ najveća prijetnja režimu, tako je s druge strane režimska cenzura ipak propuštala socijalnu literaturu koja je skretala pozornost za režim opasne nacionalne agitacije na u tom trenutku manje konfliktne, društvene probleme. Tako se, prema Štedimlijinim ocjenama, velikosrpska diktatura kralja Aleksandra poslužila socijalnom literaturom kako bi suzbila bilo kakvo iskazivanje nacionalnog izjašnjavanja. Pod okriljem pokreta socijalne literature počeo se širiti i marksizam u kulturnom životu, osobito među piscima i književnicima. Stoga „beogradska vlada dopušta ovu vrstu promičbe jer vjeruje da time skreće pažnju potlačenih naroda s glavnog pitanja, a to je njihovo oslobođenje“. Mlada generacija srpske inteligencije, za razliku od vršnjaka drugih nacija, pristupala je u kudikamo većem broju marksizmu te su je komunistički ideali posve osvojili. ${ }^{57}$

Ona se ugodno osjećala u jugoslavenskoj državi, za koju je vjerovala da je optimalno rješenje srpskog nacionalnog pitanja. Za razliku od nje, mlada inteligencija hrvatskog naroda opterećivala se nacionalnim pitanjem, pa se nije mogla olako prepustiti marksizmu i njegovim rješenjima socijalnog pitanja. Sama organizacijska struktura KPJ-a s posebnim podružnicama za Hrvatsku i Sloveniju i nepostojanjem posebne podružnice za Srbiju sve do 1945. posredno

55 Branko Petranović, Miodrag ZeČević, Razvoj narodne vlasti i stvaranje AVNOJ-a, Jugoslavija 1918.-1988.: tematska zbirka dokumenata, Beograd, 1985., 584. Osim Tita i Bakarića, i drugi protagonisti Đuro Pucar, Avdo Humo, Rodoljub Čolaković i Edvard Kardelj spominjali su prvenstvo i posebne zasluge srpskog naroda u narodnooslobodilačkom ratu i revoluciji. I. Lučić, Što je (bila) Bosna i Hercegovina i tko smo (bili) mi?, 109.

56 Ivan Jelić, Osnivanje AVNOJ-a: u povodu 30-godišnjice Prvog zasjedanja AVNOJ-a“, Časopis za suvremenu povijest, god. 4., br. 3., Zagreb, 1972., 86.

57 S. M. ŠTedimlija, Podrietlo srbskog komunizma, 7. 
svjedoči da u srpskim nacionalnim sredinama jugoslavenski identitet Partije nije bio doživljavan kao suprotan srpskom nacionalnom interesu. Za razliku od toga, u Hrvatskoj i Sloveniji KPJ prepoznala je da se samo isticanjem posebnih organizacijskih oblika s nacionalnim predznakom može djelovati u uvjetima zaoštrenog nacionalnog pitanja, ali ni to nije uspjelo KPJ pretvoriti u nositelja bilo hrvatskih, bilo slovenskih nacionalnih težnji u razdoblju prije travanjskog rata. Takav položaj KPJ u srpskim sredinama omogućio joj je brze uspjehe u pridobivanju kontrole nad ustankom srpskog stanovništva jer su Jugoslavija i Velika Srbija u njihovim pogledima u priličnoj mjeri bile sinonimne.

U ratno doba, kao i za kraljevske Jugoslavije, prevladalo je shvaćanje da su Crnogorci dio srpskog naroda sa svojim posebnostima, čemu su se priklanjali i crnogorski komunisti, nezavisno od toga jesu li potjecali iz „bjelaških“ ili „zelenaških“ obitelji. Najbolje se to izrazilo u eseju poznatog crnogorskog komunista Milovana Đilasa. Godine 1945. u tom eseju pod naslovom „O crnogorskom nacionalnom pitanju“ objavljenom u beogradskoj Borbi donio je službeni stav Komunističke partije Jugoslavije o crnogorskom nacionalnom pitanju. Nakon što su se Crnogorci uzdignuli na status nacije, a Crna Gora postala federativna republika Titove Jugoslavije, Đilas iako priznaje posebnosti povijesne crnogorske nacije, ipak pripisuje Crnogorcima srpsko etničko podrijetlo jer „Crnogorci, nesumnjivo, pripadaju srpskoj grani jugo-slovenskih plemena“. ${ }^{58}$ Štedimlija je sasvim suprotno Đilasovu i partijskom mišljenju opovrgavao čisto srpsko etničko podrijetlo Crnogoraca, dok je shvaćajući naciju kao zajednicu zajedničke sudbine i karaktera, tvrdio da su Crnogorci i Srbi imali različite povijesne putove nacionalnog razvoja.

Komunistički se kompromis u pogledu crnogorskog nacionalnog pitanja zapravo usuglasio $s$ velikosrpskom idejom, premda je prividno tražio srednje rješenje između pripojenja, koje su u ratu zagovarali velikosrpski crnogorski četnici, i odcjepljenja od srpskog političkog i kulturnog identiteta, koje su zagovarali crnogorski nacionalisti. Đilas ga je $u$ ime partije razvio, ali i utjelovljavao kao potomak bjelaša i komunist. Tako se praktički zadržao status quo, jer ni revolucionarna komunistička vlast nije prekinula stare dogme iz predratne Jugoslavije o tome da se crnogorsko pitanje ne može uzeti u obzir izvan kruga srpskog nacionalnog pitanja i da su Crnogorci dio šireg srpskog etničkog korpusa. Time je „komunističko srpstvo druge Jugoslavije“ u biti bilo „ideološkopolitički kompromis sa načertanijevsko-karađorđevićevskim svesrpstvom“.

58 Milovan Đilas, O crnogorskom nacionalnom pitanju, Borba, 1. V. 1945. u: Milovan ĐILAS, Članci 1941. - 1946., Beograd, 1947., 219. 
Drugim riječima rečeno, jugoslavenski i crnogorski komunisti prenijeli su u novo revolucionarno doba staru dogmu o srpstvu Crnogoraca. ${ }^{59}$

$\mathrm{Na}$ kraju svega, Štedimlija je smatrao da su komunistički pokret i partizanstvo u Crnoj Gori zapravo bili plod politike beogradskog režima koji je pod svaku cijenu, pa i toleriranjem širenja marksizma, htio obuzdati crnogorski nacionalni pokret pod neformalnim vodstvom Sekule Drljevića. ${ }^{60}$ Ciljje takve politike bio da se u onim dijelovima gdje je postojao najveći otpor velikosrpskom režimu kao u Hrvatskoj, Crnoj Gori i Makedoniji, dopuštalo širenje komunističke ideje, koja bi s određenom dozom nacionalnog nihilizma otupila oštricu nacionalnih pokreta u tim krajevima. Vladajući Beograd dao je prešutnu potporu komunistima jer je jednima i drugima prvi cilj očuvanje Jugoslavije od raspada, a drugi zajedničko neprijateljstvo prema nacionalističkim pokretima u prvom redu Hrvata, Makedonaca i Crnogoraca. ${ }^{61}$

59 Zeković opširnije razvija tezu o dogovoru komunističke i načertanijske ideologije u pitanju etničkog porijekla Crnogoraca. Sreten Zeković, Imperijalna istor(iolog)ija, Cetinje, 2012., 23, 5 29. Da je tomu tako potvrđuju i činjenice da su zagovornici crnogorske autohtonosti u odnosu na srpsku naciju u drugoj Jugoslaviji doživljavali napade, osude, prijetnje i etiketiranja da su „zelenaši“, „fašisti“, „rasisti“, „ustaše“ od službenih političkih i historiografskih krugova. Zbog ustrajanja u svojim tezama i otpora među drugovima komunistima, Brković je napustio Savez komunista, i to u svojstvu narodnog heroja Jugoslavije. Vidi djela napadanih autora: Savo BRKović, O postanku i razvoju crnogorske nacije, Titograd, 1974.; Špiro Kulıšıć, O etnogenezi Crnogoraca, Titograd, 1980. I drugi jugoslavenski komunisti koji nisu bili Srbi i Crnogorci branili su službenu dogmu jugoslavenskog režima, tako je Stipe Šuvar još krajem 1980-ih kada se zahuktavala „,antibirokratska revolucija“ istakao da su „korijeni nacionalizma žilavi i u Crnoj Gori koji je separatistički i prvenstveno usmjeren protiv srpskog naroda s kojim crnogorski narod kao dvije savremene nacije dijeli isto etničko porijeklo i mnogo toga zajedničke kulture i istorije do najnovijeg vremena“. Šuvarov intervju bio je dan titogradskom listu Pobjeda 25. 11. 1988. Branko Đ. NiKAČ, Crnogorski narod i nacija su istorijske i aktuelne činjenice, Cetinje, 2003., 16.

60 Sekula Drljević rodio se u mjestu Ravni kod Kolašina u Crnoj Gori 1884. Bio je crnogorski političar, pravnik i publicist. Studij i doktorat prava završio je u Zagrebu. U vrijeme Prvog svjetskog rata zastupao je velikosrpsku politiku u Crnoj Gori. Kasnije se pretvorio u kritičara jugoslavenskog unitarizma i zagovaratelja crnogorske posebnosti i pretvaranja Jugoslavije u federaciju. Radi toga postaje jedan od prvaka Crnogorske federalističke stranke i njezin najistaknutiji član. Surađivao je u političkim koalicijama s HSS-om i za vrijeme Radića, a kasnije i Mačeka. Nakon proglašenja Banovine Hrvatske isti je status predlagao za Zetsku Banovinu, odnosno tražio je da se ona pretvori u Banovinu Crnu Goru. Istakao se na Petrovdanskoj skupštini na Cetinju 12. srpnja 1941. kada je proglašena nezavisna Crna Gora pod protektoratom fašističke Italije. U listopadu 1941. talijanski guverner Pirzio Biroli dao ga je konfinirati u San Remu, nakon čega je stupio u suradnju s Mihailovićevim četnicima. Nakon sloma Italije u rujnu 1943. vratio se u Zagreb gdje je u ljeto 1944. osnovao Crnogorsko državno vijeće. Nakon povlačenja crnogorskih četnika prema Sloveniji i Austriji, oni ga kod Judenburga 10. studenog 1945. ubijaju.

${ }_{61}$ S. M. ŠTedimlija, Partizani o sebi, 81. Štedimlija kaže da se od početka diktature 1929. „ugušuje svaki list nacionalističkog opredjeljenja, dotle komunistički nesmetano izlaze i šire se među radništvom i mladeži. Sve se to vrši pod vidom socialne književnosti, ali je u stvari glavno komunistička promičba, a nipošto neka umjetnička književnost“. 
$S$ tom razlikom da se beogradski režim u pitanjima organizacije države i društva suprotstavljao u to vrijeme i federalizaciji i revolucionarnoj preobrazbi Jugoslavije što su zagovarali jugoslavenski komunisti. Razvoj nacionalnih pokreta prije svega hrvatskog nacionalnog pokreta 1930 -ih, ali i drugih, otvorio je tako prostor paradoksalnog saveza komunista i kraljevskog režima, u onom segmentu kada se trebalo oduprijeti nacionalnim pokretima te sačuvati jugoslavensku cjelinu.

\section{SRPSKI PROSTORI NA BALKANU - „KOLIJEVKA HAJDUČIJE“}

Osim korijena srpskog komunizma u ratu, pokušavao je Štedimilija dati odgovor na pitanje koji su to predmoderni čimbenici uvjetovali izljeve brutalnog nasilja i masovnih zločina koji su u ratu počinili partizani i četnici. U Štedimlijino doba bilo je jako popularno pisati o karakteru pojedinih naroda i o vezama etnologije i psihologije, čime se osobito istakla svojevrsna knjiga epohe koju je 1939. dao objaviti Vladimir Dvorniković pod naslovom Karakterologija Jugoslovena. ${ }^{62}$ Dvorniković je pod pojmom Jugoslovena, ne samo kod Srba nego i kod hrvatskog korpusa u Lici, Dalmatinskoj Zagori, Bosni i Hercegovini, također nalazio tragove hajdučkog mentaliteta i prošlosti. ${ }^{63}$

Pod utjecajem rasprava oko tih pitanja i toga djela, „, hajduštvo jugoslavenskoga naroda" o kojem je kao jugoslavenski integralist Dvorniković pisao, sveo je Štedimlija na pisanje o hajdučkom karakteru srpskog naroda. Za razliku od Dvornikovića, koji se bavio i pozitivnim stranama hajduka, Štedimlija je tražio isključivo mane i negativne strane njihova duha, kako bi dokazao svoje teorije o uzrocima zločina i nasilja partizana. Proglašenje Nezavisne Države Hrvatske i izbijanje rata u njoj ljeti 1941. po njegovim su uvjerenjima „dali (...) samo povoda, da dođe do punog izražaja jedan hajdučki, partizanski mentalitet i da se ispolje u mnoštvu nasilja i zločina“. Štedimlija je smatrao da je to „zadnji trzaj jednog organizma“ koji je bio „zadahnut i prožet duhom i mentalitetom partizanstva pod kojim se imenom njegovi nosioci s ponosom pojavljuju izspisujući ga na svojim krvlju obojenim crvenim zastavama" ${ }^{64}$ Posljedično tomu, srpske prostore na jugoistoku Europe identificirao je kao „kolijevku hajdučije“. Stoljeća nepostojanja državne vlasti, zakona, reda, mira i sigurnosti urodila su stvaranjem posebnog mentaliteta kod srpskog naroda. Štedimlija je u srpskom povijesnom mentalitetu tragao za uzrocima partizanskog i četničkog nasilja i masakra nad

62 Vladimir Dvorniković, Karakterologija Jugoslovena, Beograd, 1939.

63 Vladimir Dvorniković, Karakterologija Jugoslovena, 551 - 553.

64 S. M. Š Tedimlija, Partizani o sebi, 25-26, 32. 
stanovništvom NDH. U tome je povijesnom naslijeđu uvjetovanom kulturom nasilja tražio razloge ratnog ponašanja partizana i četnika. U ovoj svojoj studiji pod naslovom Partizani o sebi iz 1944. zahvatio je čitavu povjesnicu srpskog hajduštva od Dušanova carstva do pred Drugi svjetski rat. I nakon 1918. godine u Srbiji su divljali hajduci koji su kršili zakone, uništavali živote i imovinu, a neki od njih su bili čak i predstavnici vlasti. ${ }^{65}$

Njegovo pozivanje u toj stvari nije se temeljilo na pukoj propagandističkoj konstrukciji, nego na citiranju eminentnih poznavatelja srpske narodne kulture kao što su bili Baltazar Bogišić, Dušan Popović, Sima Milutinović i Vuk Karadžić. Tragajući u prošlosti za korijenima te kulture nasilja, upozoravao je na „hajdučiju“ koja je svojim ponašanjem postala uzorom narodne kulture srpskog naroda. ${ }^{66} \mathrm{U}$ srpskim narodnim pjesama ukazivao je na kulturu nasilja i osvete koje su njegovali postupci „srpskog hajduštva“ pod turskom vladavinom. ${ }^{67}$ Tako se o hajducima „djeci u školama govorilo kao o braniteljima od tudjinskog nasilja i kao o nosiocima narodnih ideala iz težkih dana borbe i oslobodjenja iz robstva“. Time je hajduk u narodnoj mašti stekao „aureolu mučeništva i svetosti“ putem narodne poezije i književnosti. Nacionalni romantizam 19. stoljeća je hajduka, pljačkaša i ubojicu pretvorio u nacionalnog heroja prvog reda. U romantičarskom se duhu bilo kakvoj hajdučkoj djelatnosti pripisivala politička motivacija. Tako

65 S. M. ŠTedimlija, Partizani o sebi, 25 - 26, 32. Spominje među brojnim izvještajima u crnoj kronici beogradskih listova o međuratnoj hajdučiji čak tri takva slučaja koje je evidentirao u beogradskim novinama. U prvom je prema vijestima od 27. ožujka 1923. redarstvo Vračarskog kotara uhvatilo grupu razbojnika i kradljivaca koje je predvodio Jovan Sandić, službenik državnog poduzeća za telegrafiju i telefoniju. U Pljevljima je, prema pisanju beogradskih Novina, sreski poglavar Ljuba Damjanović 9. veljače 1927. ubio u manastirskoj ćeliji svećenika Ristu Nenadića rasporivši mu trbuh i bio organizatorom drugih ubojstava i pljački u svom srezu. U jednom selu 20. kolovoza 1927. novine su javile da je kod Niša lokalni općinski predsjednik otkriven kao „razbojnički harambaša“.

66 Branimir Anzulović, Mit o nebeskoj Srbiji, Zagreb, 67 - 95. Anzulović se nije podrobno bavio situacijom u Drugom svjetskom ratu, nego više srpskom kulturnom povijesti i razlozima i motivima ratova koje su Srbija i srpski narod vodili nakon raspada Jugoslavije 1991. godine. Iako autor u svojoj knjizi izrijekom ne citira Štedimlijina djela, dolazi do njemu bliskih zaključaka o naravi „balkansko patrijarhalne-herojske kulture.“ Na tragu sličnosti Štedimlijine rasprave o hajduštvu pisao je i Ivo Rendić Miočević, ali nije čitao njegove tekstove o ovoj temi, vjerojatno jer je ovaj bio nepoćudni autor, koga se dugo nije smjelo citirati i istraživati. Za razliku od Štedimlije, Rendić-Miočević svoju je raspravu proširio i na Muslimane i Hrvate. Povod knjizi su krvavi ratovi na prostoru bivše Jugoslavije u 20. stoljeću i traženje njihova objašnjenja, vidi: Ivo RENDIć MiočEvić, Zlo velike jetre - povijest i nepovijest Crnogoraca, Hrvata, Muslimana i Srba, Split, 1996., 51 - 279.

67 S. M. Štedimlija, Uzori Draže Mihajlovića i partizana, Zagreb, 1943., 3 - 7. Kao motive pisanja ove materije Štedimlija je navodio vijest o pečenju na ražnju trojice ustaša. I Tomasevich u svojoj knjizi kada govori o tradiciji četništva dovodi ga u vezu s hajduštvom i gerilskim ratom, koja je bila običaj suprotstavljanja balkanskih naroda osmanlijskoj sili. No, on nije zadirao u dublje analize „hajdučkog mentaliteta“, nego se bavio faktografskim činjenicama od Prvog srpskog ustanka do 1941. Jozo Tomasevich, Četnici u drugom svjetskom ratu, 113 - 118. 
da su u narastajućem srpskom nacionalizmu 19. stoljeća ovi postajali nacionalni borci za slobodu od turske vladavine. Naime, čitavi je srpski vojni i politički vrh stasao u 19. stoljeću vukao svoje korijene iz hajdučkih redova, uključujući tu i dinastije Obrenovića i Karađorđevića. Zato je i pisao da su „u to vrieme hajdučki prvaci postajali vojvode, ministri i narodne vodje, a dvojica od njih Karadjordje i Miloš Obrenović bili su državni poglavari““ ${ }^{68}$ Da su bivši hajduci kao moderni nacionalni vođe unijeli u mladu srpsku državu sklonost sukobima i nasilju, pokazuje i činjenica mnogobrojnih ratova koje je Srbija vodila do Prvog svjetskog rata. To su ratovi s Turskom 1876. - 1878., Bugarskom 1885. te naposljetku Prvi i Drugi Balkanski rat koje je vodila 1912./13. i 1913. Kao i sklonost pribjegavanju političkim atentatima od kojih su najpoznatiji Majski prevrat 1903. kada je nasilno svrgnuta vladarska kuća Obrenović te Sarajevski atentat 1914. prilikom čega je ubijen austrougarski prestolonasljednik Franjo Ferdinand. ${ }^{69}$

Po Štedimliji su srpski nacionalni ustanci bili do tolike mjere romantizirani da su od prekomjernog idealiziranja skrivali njihovu pravu narav jer su se hajduci prilikom pobune protiv turske vlasti okomili i na srpsko seljaštvo ubijanjem, razbojstvima i pljačkom. Taj je duhovni mentalitet hajduštva prema Štedimliji dugog povijesnog trajanja ostao netaknut u srpskom narodu te se otvoreno izrazio u metodama ratnog djelovanja partizanstva i četništva. Iz toga razloga djelatnost partizana i četnika „ne predstavlja ništa novo i ona imade svoj korien preko 500 godina unatrag, u poviesti nekih balkanskih naroda“.'Zato se usuđivao govoriti da je „cielo prošlo stoljeće izpunjeno dogadjajima, koje su na Balkanu izazivali hajduci i odmetnici raznih vrsta, te se može smatrati, da nema ni jednog nacionalnog, vjerskog ili političkog pokreta, koji bi tako snažno bio zahvatio tamne sile Balkana kao hajdučija i sve šta sa njom stoji u vezi“. Štedimlija je bio spreman naglasiti da se partizanska i četnička gerila odvijala upravo na istom geografskom prostoru gdje su stoljećima djelovali hajduci širom dinarskog masiva od bivše Vojne Krajine preko bosanskih planina do sjeverne Crne Gore i Zapadne Srbije, pa i na osnovu istih zemljopisnih točaka ocrtava duboku povezanost hajduka i suvremenih partizana i četnika. Spominjao je posebno istočno-bosansku planinu Romaniju, koja je imala istaknuto mjesto u povijesti srpskog hajduštva, a koja se kasnije zbog svoje važnosti kao partizansko uporište utkala u revolucionarnu memoriju jugoslavenskih komunista. ${ }^{70}$ 
Stoga, koliko se god komunistička revolucija u Jugoslaviji trudila putem ratne propagande, ali i kasnije prikazati kao nešto dotada neviđeno i apsolutno novo, kao nepatvoreni modernizam i progresistički iskorak jugoslavenskih naroda, u njezinim dubinama su, prema Štedimlijinim zaključcima, ključale stare aveti prošlosti herojske kulture Balkana. Sve u svemu, njegovo je objašnjenje fenomenologije partizanskog pokreta postalo kanon za smjer javnog, intelektualnog i političkog diskursa u NDH. Opisujući srpske prostore kao „kolijevku hajdučije“ u kojoj su se začeli i partizanski, ali i četnički pokret, na neki je način objedinio stavove skoro svih protagonista (Mladen Lorković, Julije Makanec, Matija Kovačić, Danijel Crljen, Vilko Rieger, Ivo Bogdan), koji su govorili i pisali u ratnom tjedniku Spremnost o toj temi u Štedimlijino doba.

\section{ZAKLJUČAK}

Savić Marković Štedimlija se rodio i odgojen je u Crnoj Gori, školovao se u Srbiji, studirao u Zagrebu, a kao istaknuti mladi komunist $s$ velikim interesom za povijest Srba (i Crnogoraca), bio je najpozvaniji da se zaputi u proučavanje podrijetla srpskog komunizma. Štedimlija svojim pisanjem o partizanskom pokretu nije podcijenio stoljetnu povijesnu i kulturnu razmjenu između ruskog i srpskog naroda. Ruski socijalizam 19. i kasniji boljševizam 20. stoljeća imali su neprijeporan utjecaj na srpske moderne elite, a posredno i na srpski narod u cjelini. Čitava moderna srpska kultura bila je premrežena utjecajima socijalizma, a neki od njezinih glavnih protagonista bili su najveći zagovornici te ideologije. Pažljivim pristupom temi obradio je prodor socijalističkih ideja i komunističke misli u različite slojeve srpske elite, od svećenstva, preko vojske i inteligencije do politike koji su se odigrali daleko prije samih ratnih zbivanja. Prošle veze srpske kulture sa socijalističkim i marksističkim tradicijama stvorile su plodno tlo za erupciju srpskog komunizma pod vodstvom Komunističke partije Jugoslavije u ratu. Kod ovoga je važan stari kult Rusije u vjerskom i kulturnom životu pravoslavnih naroda Srba (i Crnogoraca), koji je također stvorio pogodne uvjete za širenje komunističkih ideja, osobito nakon boljševičke revolucije. Objašnjavao je da unatoč načelnom internacionalizmu lijeve ideologije nikada srpski tip socijalizma, odnosno komunizma, nije odbacio srpsku nacionalističku misao. Dapače, prema Štedimlijinom mišljenju, u srpskom komunizmu kakav se rađao u ratnim okolnostima, nikada nije bio snažno izražen anacionalni duh, koji bi istisnuo srpski nacionalistički mit. Ostaje nedvojbeno da se partizanski pokret ne bi mogao održati u ratu da nije naišao na ogromnu podršku srpskog naroda 
u Crnoj Gori i NDH. Sve do 1943. srpski je nacionalni korpus nedvojbeno osovina partizansko-komunističkog pokreta. Zato se usuđuje kazati da je Garašaninov plan iz 1844. istovjetan ciljevima jugoslavenskih komunista, među kojima su Srbi u većini. Iz te spoznaje postaje razumljivo zašto je Štedimlija partizanski pokret od njegova početka okarakterizirao kao velikosrpski pokret, kojem je cilj uništenje hrvatske države i obnova Jugoslavije koja jedina može okupiti srpski narod u jednoj državi. Pristupanje drugih skupina, u prvom redu Hrvata i muslimana u većom broju u partizanski pokret posebno od 1943., nije kod Štedimlije dovodilo u pitanje njegove velikosrpske izvore. Zato jer etnička prisutnost drugih nacionalnih i vjerskih skupina u tom pokretu nije mogla po njegovu mišljenju promijeniti njegovu izvornu velikosrpsku narav. U pogledu ostvarenja velikosrpskih ciljeva partizanski pokret se tako nimalo ne razlikuje od četničkog pokreta, nego se njihov sukob odigravao na starim prepirkama srpske politike i odabira između monarhističkog i republikanskog poretka. Ta dva politička načela podijelila su i srpski nacionalni korpus. Izvan granica Kraljevine Srbije, tzv. prečanski krajevi koji su se tek 1918. našli pod dinastijom Karađorđevića pokazali su se u većoj mjeri skloniji zovu komunizma. Drukčije su se ponašala područja unutar granica Kraljevine Srbije prije Prvog svjetskog rata u kojima je postojala duža monarhistička tradicija i u kojima je i za rata ostala prevladavati privrženost kraljevskoj dinastiji i četničkom pokretu. Uzroci zločina i nasilja koje je provodio partizanski pokret imali su prema Štedimliji korijene u srpskom hajduštvu koje se osobito razvilo za turske vladavine nad srpskim zemljama. Hajdučki mentalni sklop bio je drugi okidač nakon srpskog socijalizma koji je dao zamaha razvoju srpskog komunizma i partizanskog pokreta. Budući da se hajduštvo i revolucija, naoko dvije nepovezane povijesne stvarnosti, dodiruju u onoj točki u kojoj oboje zagovaraju, opravdavaju i veličaju upotrebu nasilja na putu ispunjenja svojih ciljeva. Zahtjev da se Drugi svjetski rat u poslijeratnoj politici, historiografiji i publicistici prikaže u duhu „bratstva i jedinstva jugoslavenskih naroda“, prisilno je iskonstruirao podjednaki doprinos svih tih naroda partizanskom pokretu. Naknadna jugoslavizacija partizanskog pokreta u biti je prekrila njegove prvotne izvore i nadahnuća. To je u dubokom raskoraku sa Štedimlijinim osnovnim mislima. A one su takve da su partizanski pokret i borba jugoslavenskih komunista nezamisliva bez srpskog nacionalnog bića, koji je bio nosivi stup njihova, kako su ga nazivali, narodnooslobodilačkog rata. Ta je njegova konstatacija trebala spriječiti i odljev hrvatskog stanovništva u partizane u drugom dijelu rata. 
Stipe KLJAJIĆ

\section{SAVIĆ MARKOVIĆ ŠTEDIMLIJA ABOUT THE ORIGINS OF SERBIAN COMMUNISM AND THE PARTISAN MOVEMENT}

\section{SUMMARY}

Savić Marković Štedimlija was a Montenegrin writer and publicist. He participated in the Croatian public life from the thirties to the end of the Second World War. His arrival in Zagreb, which was then in a turmoil of the Croatian national movement against the Belgrade dictatorship, Yugoslav nationalism and communist propaganda greatly influenced his later views. In Zagreb, his Montenigran nationalism became more elaborated and articulated while writing his most renowned works on Montenigran issues. At the same time, he abandoned his left-wing orientation. He defended the war attempt of Montenegrin and Croatian independence and declared himself as an enemy of the common Yugoslav state. He also invested a lot of effort to explain the occurrence of the Partisan and Chetnik movement in the Second World War. Given that the Partisan movement posed much more severe danger to the existence of the Croatian war-time state, he consequently gave it more space in his writing. He, therefore, tried to make it clear why the Partisan movement spread among the Serbian people so rapidly under the decisive leadership of Serbian and Yugoslav communists.

Keywords: Sava Marković Štedimlija, Partisan movement, Serbian communism, The Independent State of Croatia. 
